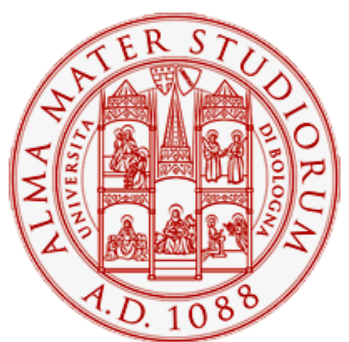

Alma Mater Studiorum - Università di Bologna DEPARTMENT OF ECONOMICS

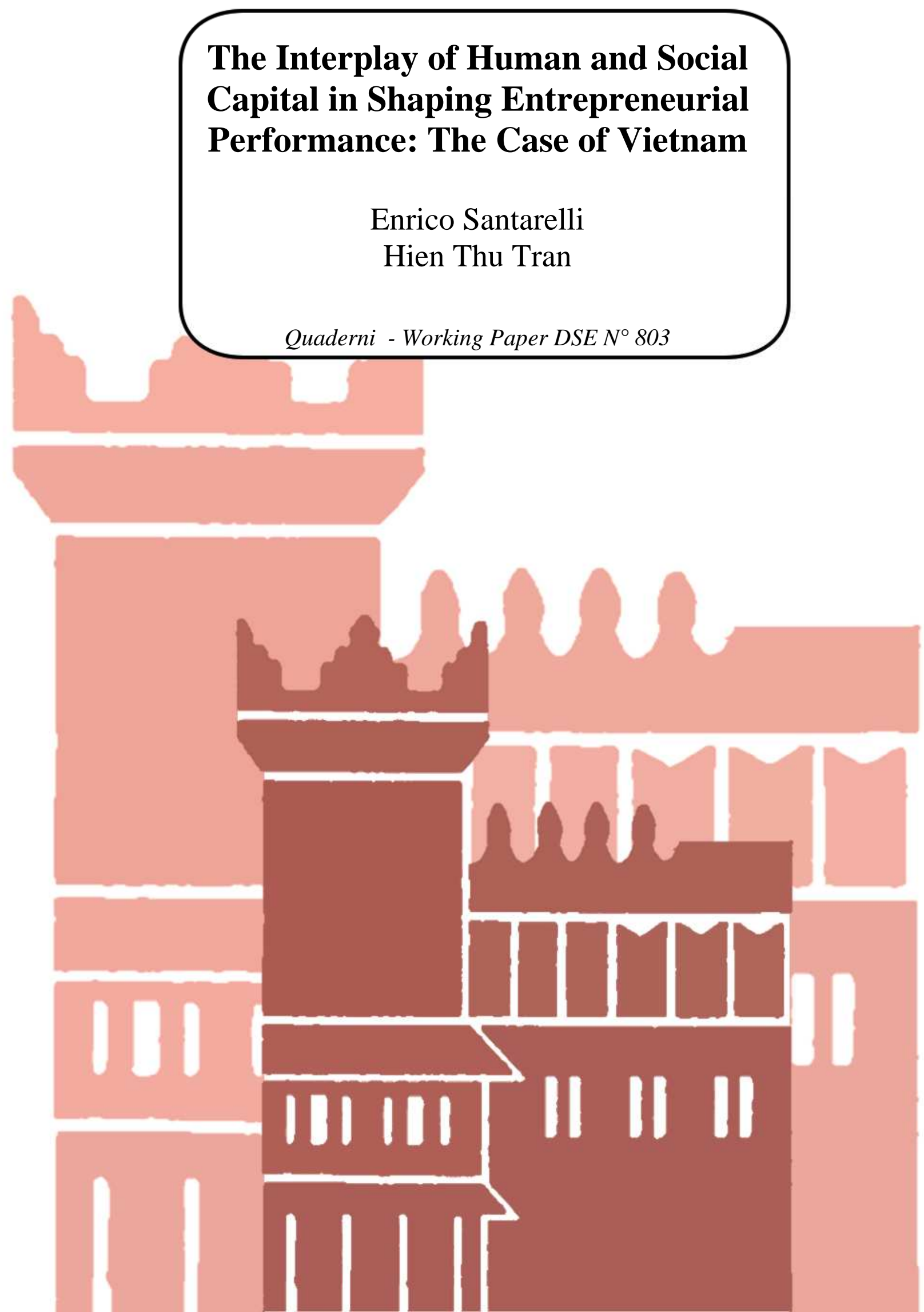




\title{
The Interplay of Human and Social Capital in Shaping Entrepreneurial Performance: The Case of Vietnam
}

\author{
by \\ Enrico Santarelli \\ University of Bologna, Department of Economics; Piazza Scaravilli, 2 - 40126 Bologna, Italy; \\ tel. +39051 2098487; e-mail: enrico.santarelli@unibo.it \\ Hien Thu Tran \\ Centre of Commerce and Management- RMIT International University; Hanoi, Vietnam \\ tel: +84904 797597; e-mail Hien.Tran@ rmit.edu.vn
}

January 10, 2012

\begin{abstract}
This study investigates the effects of human capital, social capital and their interaction on the performance of 1,398 Vietnamese new-born firms. Operating profit is used as the measure of success. Human capital is captured by individual-level professional education, start-up experience, and learning. Whereas the first two dimensions of human capital are measured with traditional indicators, we define learning as ability to accumulate knowledge to conduct innovation activities (new product introduction, product innovation and process innovation). Social capital is measured as benefits obtained from personal strong-tie and weak-tie networks. Key findings are three-fold: (i) human capital strongly predicts firm success, with learning exerting a statistically significant positive impact on operating profit; (ii) benefits from weak ties outweigh those from strong ties; (iii) interaction of human capital and social capital displays a statistically significant positive effect on new-firm performance.
\end{abstract}

Keywords: Human capital; Social capital; Entrepreneurship; Performance of entrepreneurial firms; Vietnam.

JEL Classification: L26; L25; L14; J24; O53 


\section{Introduction}

Many authors have studied the effects of human capital and social capital on entrepreneurial performance, usually picking-up either human capital alone (Cooper et al., 1994; Van Praag and Cramer, 2001) or social capital alone (Yoon, 1991; Aldrich and Reese, 1993; Bates, 1994; Pennings et al., 1998) rather than their combination. Thus, the literature on the interplay of human and social capital as drivers of successful entrepreneurship is still relatively limited, with some scholars arguing that they are substitutes, and others seeing them as complements. Among others, Bruderl and Preisendorfer (1998) state that social capital compensates for shortcomings in human capital, whereas Piazza-Georgi (2002) submits that investment in human capital leads to a loss in social capital, since individuals are unable to invest simultaneously in both.

Human and social capital are seen as complements in the sociological literature (Sanders and Nee, 1996), just as human and physical capital are seen as complements in the economic literature (Abramovitz, 1989; Szirmai, 2008). Therefore, a considerable gap exists in the literature on how social capital originating from personal networks of the entrepreneur interacts with her/his own human capital to generate knowledge for new venture development.

We aim to bridge this gap by investigating also the effect of the interaction of human and social capital on entrepreneurial performance. Our study exploits longitudinal data of Vietnamese Small and Medium Sized Enterprises (SMEs) extracted from the Danish International Development Agency (DANIDA) survey carried out by the Ministry of Labor, Invalids and Social Affairs in Vietnam (MOLISA) and the Department of Economics of the University of Copenhagen. The two-year panel dataset, drawn from the surveys conducted in 2005 and 2007, contains information on 1,398 start-ups created in Vietnam from 1995 to 2005. The econometric strategy adopted is ordinary least squares (OLS) regression with robust standard errors.

Consistent with comparable empirical research for developed countries (Van Praag, 2005; Parker and Van Praag, 2006), our findings show that human capital categorized into education, experience and learning plays a significant role as key determinant of successful entrepreneurship. Measuring the effect of social capital as the benefits obtained from personal strong-tie and weak-tie networks, our findings support Granovetter (1973) and Davidsson and Honig (2003), but contradict Bruderl and Preisendorfer (1998), showing that benefits from weak-tie networks outweigh those from strong-tie networks. Weak ties give entrepreneurs access to various types of 
resources that are unlikely available within strong-tie interactions. However, the statistical and economic effects from participating in formal business networks (weak ties) reduce once ownership types are controlled. This may be due to the fact that the transition experience in Vietnam is half-way, with networks still being mainly politicsbased, rather than business-oriented.

The most important finding in our study is that entrepreneurs generate higher profit if their social capital and human capital are more advanced. We found positive relations between entrepreneurial performance one side and the interaction of network participation and high educational level as well as the interaction between network participation and start-up experience on the other side.

The paper is organized as follows. Section 2 reviews the relevant literature and draws the main hypotheses. Section 3 presents the dataset. Section 4 sets up the empirical models and discusses the results. Finally, section 5 summarizes the main findings and gives some hints for future research.

\section{Theoretical Framework}

\subsection{Human Capital and Entrepreneurial Performance}

In economic theory human capital is assumed to be one of the main drivers of successful entrepreneurship, increasing the owners' capacity to perform generic entrepreneurial tasks and to discover and exploit business opportunities (Becker, 1964; Shane and Venkataraman, 2000). Not only does human capital help owners to plan for future goals and acquire other resources such as financial and physical capital (Brush et al., 2001), but also facilitates the acquisition of new knowledge and skills (Barney, 1995; Cohen and Levinthal, 1990). Human capital has been argued to play an even larger role in knowledge intensive activities entailing rapid change and new requirements in the work place (Honig, 2001; Pennings et al., 1998; Bosma et al., 2004; Sonnentag and Frese, 2002). To sum up, start-up entrepreneurs with a greater endowment of human capital should be more efficient in running their business than those with less human capital. Thus, we submit the following hypothesis:

Hypothesis 1: There is a positive relationship between human capital and the success of start-up firms.

So far, empirical findings have provided mixed results about the magnitude of the human capital/entrepreneurial success relationship. Reuber and Fisher (1994) review 
eight studies testing this relationship, identifying eleven significantly positive effects, eleven non-significant effects, and two significantly negative effects. Relationships between human capital and success have been described as "spotty and difficult to interpret" (Reuber and Fisher, 1994: 370), "somewhat inconclusive" (Honig, 2001: 579), and "mixed, inconclusive on the whole" (Florin et al., 2003, p. 375). Baum and Silverman (2004, p. 411) claim that venture capitalists "appear to make a common attribution error overemphasizing the human capital embodied in startups when they make their initial investment decisions". In short, the field of entrepreneurship research so far has failed to adequately explain the differential effects of human capital attributes and to provide a framework to illuminate why and what kind of human capital should be related to success.

To obtain conclusive answers on whether human capital has a positive relationship with entrepreneurial performance, it is necessary to examine the role of its subcomponents in such a relationship, particularly the role of education (referred to as prior knowledge), experience and learning. Among such sub-components, past empirical studies have shown that prior knowledge strongly influences successful entrepreneurship (Pickles and O'Farrell, 1987; Storey, 1994; Van der Sluis et al., 2003; Bosma et al., 2004; Parker and van Praag, 2006, Hamilton, 2000). In fact, it increases a person's stock of information and skills useful for the pursuit of an entrepreneurial opportunity, improves entrepreneurial judgment (Shane, 2000: 94), boosts business owners`entrepreneurial alertness (Westhead et al., 2005), and prepares entrepreneurs to discover opportunities that are not apparent to others (Shane, 2000; Venkataraman, 1997). Storey (1994) highlights the result found in many empirical studies that the educational attainment of the entrepreneur is an important positive determinant of the growth of her/his firm. Recently, Van der Sluis et al. (2003) have performed a comprehensive meta-analysis of 94 studies estimating the relationship between schooling and entrepreneurial entry and performance. They conclude that schooling, irrespective of how it is measured, significantly and positively affects entrepreneurial performance. A similar result is also found for the case of Dutch entrepreneurs by Bosma et al. (2004) and Parker and van Praag (2006), who argue that schooling has also an indirect effect on entrepreneurship by easing the capital constraints faced by new ventures. Hamilton (2000) found that earnings are lower among self-employed who are high school drop-outs, and higher among college graduates. 
In considering the effects of experience on entrepreneurial performance, it is helpful to distinguish between four distinct types of experience: labor force experience, industry experience, occupational experience and entrepreneurial experience. The effects of labor force experience on venture performance are generally weak. There is little evidence suggesting that general labor force experience has a meaningful impact on new venture performance (Hamilton, 2000; Bosma et al., 2004). In contrast, the effects of industry experience on entrepreneurship have been found to be strong: Entrepreneurs are more likely to be successful if they have pre-existing knowledge of buyers and suppliers, and understand operational issues in their industry (Bruderl and Preisendorfer, 1998; Bruderl et al., 1992; Reynolds, 1993; Bates and Servon, 2000; Lerner and Almor, 2002; Bosma et al., 2004). Regarding occupational experience, scholars have often assumed that managerial experience has the greatest relevance. In this connection, some studies have suggested that managerial experience should improve entrepreneurial performance because entrepreneurship plays a core organizing function (Say, 1971, in Van Praag, 2005). However, the experience may be more relevant in less hierarchical corporations: If entrepreneurs have some degree of autonomy and control, as in the case of many small firms, they can transform such managerial experience to entrepreneurial skills. In contrast, in very large and hierarchical firms most entrepreneurs perform routinized tasks. The empirical evidence supports the argument that the effect of managerial experience upon entrepreneurship is mixed (Bosma et al., 2004; Gimeno et al., 1997). Finally, the effects of prior entrepreneurial experience (self-employment experience) on entrepreneurship are positive. While some of the information and skills necessary to exploit a business opportunity can be learned through education or through managerial and industry experience, most of the important information and knowledge about exploiting opportunities can only be learned by "doing" (Jovanovic, 1982; Hebert and Link, 1988). Empirical studies generally support this positive relationship (Gimeno et al., 1997; Bosma et al., 2004; Holmes and Schmitz, 1996; Taylor, 1999; Reynolds, 1993; Lerner et al., 1995; Evans and Leighton, 1989; Santarelli et al. 2009; Santarelli and Tran, 2011; Schiller and Crewson, 1997).

The third component of human capital - learning - is receiving growing attention, both on the part of academics and practitioners (Harrison and Leitch, 2005; Reuber and Fisher, 1994; Shane, 2000, Sonnentag and Frese, 2002). Learning is the continuous process that generates knowledge, which is categorized into vicarious learning (learning 
by observing) and experiential learning (learning by doing). Shane (2000) emphasizes the importance of vicarious learning to the extent that much of the information and skills necessary for the exploitation of entrepreneurial opportunities can be learned through observation of others. In general, learning and knowledge are central for small businesses and their success (Levinthal and March, 1993; Zahra and George, 2002). From a resource-based view, learning and the ability to change are among the most important capabilities that firms can possess (Barney et al., 2001). It is therefore surprising that research on learning in entrepreneurship is still in its early stages (Ravasi and Turati, 2005), with only a few empirical studies having focused so far on how business owners learn and accumulate relevant knowledge.

Many researchers, including Schumpeter (1934), Kirzner (1997), Minniti and Bygrave (2001), Shane and Venkataraman (2000), Malerba (2007) agree on the importance of learning throughout the entrepreneurial processes of exploring, discovering and pursuing new business opportunities. Knowledge from learning affects the owner's capacity to recognize (Shane, 2000) and evaluate valuable business opportunities, and to develop the initial idea into a new product or service (Ravasi and Turati, 2005). After the discovery of a potential opportunity, the relevant knowledge they have previously accumulated enables business owners to make better decisions and take more knowledgeable actions when faced with ambiguity and uncertainty (Minniti and Bygrave, 2001; Reuber and Fisher, 1999). The process from the initial intuition to the launch of a new product incorporates a learning process in which the owner plays the key role.

On the basis of the above hints from the relevant literature, we propose the following hypotheses:

Hypothesis 1.1: There is a positive relationship between educational level and the success of start-up firms.

Hypothesis 1.2: There is a positive relationship between industrial experience (also referred as business line experience) and the success of start-up firms.

Hypothesis 1.3: There is a positive relationship between prior entrepreneurial experience (or self-employment experience) and the success of start-up firms.

Hypothesis 1.4: There is a positive relationship between entrepreneurial learning and the success of start-up firms. 


\subsection{Social Capital and Entrepreneurial Performance}

While human capital is a combination of individual's attributes, skills, or experience, social capital is actual or potential values and benefits resulting from his/her own social interactions and networks. The notion of social capital encompasses human actions that are shaped by societal factors. According to Putnam (1993), social networks provided by extended family- or community-based relationships are likely to amplify the effects of education, experience, and financial capital. This leads to the fact that participation in social networks benefits individuals involved in start-up activities (Aldrich and Zimmer, 1986, Johannisson, 1988).

In general, the effect of social capital on entrepreneurial performance is reflected in four aspects. First, social networks give entrepreneurs access to a variety of scarce resources (Zimmer and Aldrich, 1987; Bates, 1997; and Light, 1984). Second, social networks give entrepreneurs access to intangible resources such as credibility and competence (Bruderl and Preisendorfer, 1998; Bosma et al., 2004). Third, since entrepreneurs are limited in their ability to assemble and absorb information for their decision-making process, they have to rely upon frequent external contacts, especially with distributors, suppliers, competitors, and customer organizations, to obtain necessary information and advices (Peters and Brush, 1996; Birley, 1985; Smeltzer et al., 1991; Brown and Butler, 1995). Fourth, social networks have reputational and signaling effects: Positive perceptions of a firm's network participation may lead to subsequent profitable business exchanges (Stuart et al., 1999; Calabrese et al., 2000).

A number of studies have emphasized the strong impact of both governance and structure of social networks on entrepreneurial performance. In general, the characteristics of the networks in which entrepreneurs are embedded (such as size, density, diversity, centrality, etc.) are seen as identifying the impact of network participation on business performance (for a review, see Hoang and Antoncic, 2003). However, Aldrich and Zimmer (1986), argue that these general properties could capture ability and potentiality of a personal network to provide resources to entrepreneurs, but could not give a sound measurement of how much support entrepreneurs receive from their social interactions.

Bruderl and Preisendorfer (1998, p. 213) develop, and test in relation to 1,700 new business ventures in Germany, a "network success hypothesis" which assumes a positive relation between networking activities of entrepreneurs and their start-up 
success. One of the first studies providing evidence in support of the existence of a positive network effect is Jarillo's (1989), which finds that firms exploiting intensively network resources grow more than firms using only internal resources. Ostgaard and Birley (1996) explore the effectiveness of personal networks of managers in England and confirm the importance of networks for company performance and development. Defining social capital as the connectedness of firm members and potential clients, Pennings et al. (1998) show that firm-level social capital could be the most important source of its competitive advantage, especially when the capital is specific and unique.

However, other empirical studies have not found positive network effects. For example, Bates (1994) challenges the validity of explaining success in self-employment among Asian immigrant-owned small businesses in the U.S. by observing their use of social capital. For the case of Korean immigrant businesses in Chicago, Yoon (1991) finds that ethnic resources as social capital benefits are important at the initial stage of business, but turn out to be irrelevant or insufficient at later stages where human capital becomes dominant. Aldrich and Reese (1993) also argue that networks involved in business start-up have no effect on subsequent business performance. Littunen (2000) investigates the effect of cooperation among 129 start-ups in Finland on their survival beyond the critical operational phase ( 4 to 6 years) as the criterion for success. He finds no significant correlations between networking and start-up success.

In search of uncontroversial empirical evidence some researchers recommend the adoption of Granovetter's (1973) model, in which network partners are classified in terms of "strong ties" and "weak ties". Strong/weak social ties are relations with high/low levels of emotional attachment, including the entrepreneur's family, relatives, and friends. Bruderl and Preisendorfer (1998) claim that support from strong ties is more important than support from weak ties. In the early start-up stage, the presence of strong ties appears to influence the persistence of nascent entrepreneurs to start up new ventures (Davidsson and Honig, 2003). Family members are present in entrepreneurial networks in all phases of establishing a firm (Greve and Salaff, 2003). The presence of an entrepreneur in the family can compensate for financial and managerial restrictions. Further, emotional support received from a family member who is an entrepreneur might be very helpful to sustain emotional stability. Sanders and Nee (1996) emphasize the role of family as social capital in the pursuit of economic gain of immigrant selfemployees. Accordingly, we submit the following "strong ties" hypothesis: 
Hypothesis 2.1: Entrepreneurs who receive support from their family members, relatives, and friends during the start-up phase will be more successful than entrepreneurs who do not receive any support.

Here we consider benefits from strong-tie interactions as one component of entrepreneurs' social capital, together with those from weak ties. But we are aware that a stream of sociological literature on social capital (Putnam, 1993; Fukuyama, 1995; Miguel et al., 2005) has excluded family ties from the main determinants of successful entrepreneurship and highlighted the importance of non-familiar networks.

Weak ties are based on relations devoid of any emotional attachment, such as those with acquaintances, business partners, colleagues, etc. Granovetter (1973) emphasizes the "strength of weak ties" and argues that weak ties are less reliable but more likely to provide access to a variety of new information. Based on the view of Putnam (1993), Fukuyama (1995) maintains that in societies where economic actors are capable of trusting and working with non-family members, they are capable of building larger, and more efficient organizations which are crucial to compete in modern, high-tech, and fast-growing industries. Based on the assumption that entrepreneurship consists of two related processes, discovery of entrepreneurial opportunities and exploitation of such opportunities, the analysis performed by Davidsson and Honig (2003) emphasizes the increasingly important role of weak ties that provide specific knowledge unlikely to be available within close networks of strong ties during the exploitation period. By the same token, other authors have highlighted the importance of those communities of practices which may prove helpful both for advancing technology structuring and discovering valuable uses for new technologies (Gustafsson and Autio, 2011).

We will examine the 'network success hypothesis' to understand the effect of entrepreneurs' formal business network participation on subsequent business performance. Thus, we formulate the following conditional "weak ties hypothesis":

Hypothesis 2.2: Entrepreneurs who participate in formal business networks will be more successful.

\subsection{Interaction of Social Capital and Human Capital and Entrepreneurial Performance}

To our knowledge, only a few studies have raised in a comprehensive manner the interplay of human and social capital in shaping entrepreneurial performance, none of which dealing with such issue in relation to transition economies. 
Pennings et al. (1998) use data for a population of Dutch accounting firms to study the effect of human and social capital on firm dissolution. They conclude that human capital (captured by firm tenure, industry experience, and graduate education), and social capital (captured by professionals' ties to potential clients) strongly predict firm dissolution, and the effects depends on their specificity and nonappropriability to firms.

For a sample of 1,700 German business founders, Bruderl and Preisendorfer (1998) conclude that social capital enhances the success of newly founded businesses. Support from strong ties, such as friends and family, enhance survival and sales growth, whereas support from weak ties has an effect only on sales growth. On the other hand, the network compensation hypothesis is not supported. Although no effects of human capital on the amount of social capital are found, effects of human capital on the success of new businesses are very strong.

Using longitudinal data for Swedish nascent entrepreneurs, Davidsson and Honig (2003) show that, at the individual level, factors related to human and social capital lead to both opportunity discovery and exploitation. Their main findings are that: (i) both tacit and explicit knowledge from human capital are influential during entrepreneurial discovery, but only weakly during the exploitation period; (ii) bridging and bonding social capital, consisting of both strong and weak ties, is strongly associated with probability of entry and important in predicting successful exploitation.

Bosma et al. (2004) use a large panel dataset of Dutch entrepreneurs to investigate the value of investments in human and social capital for the business performance of start-ups measured by survival, profits, and generated employment. They conclude that specific investments indeed enhance performance, irrespective of the measure used.

Focusing on a cohort of firms founded with limited financial assistance from a public policy program in the Munich region of Germany, Dencker et al. (2009) find that an entrepreneur's breadth of knowledge has a negative influence on the firm's job creation whereas the entrepreneur's leadership experience has a positive influence.

All the above mentioned studies focus on entrepreneurship in the context of advanced economies, and the findings are still mixed and inconclusive. Besides, they do not address directly the interplay of human and social capital and to not give any indication regarding the fact that human capital and social capital should be understood as complements or substitutes (Rooks et al., 2009). The notion that human capital and social capital are complementary forms of capital can be traced back to Coleman (1988). He argues that social capital in the family as well as in the community promotes 
the formation of human capital. Burt (2001) shares the same opinion when stating that "social capital is the contextual complement to human capital" (:32). The opposite line of thinking supports the substitutability of human and social capital. Bruderl and Preisendorfer (1988) with the so-called 'network compensation hypothesis' and PiazzaGeorgi (2002) argue that entrepreneurs who lack a particular source of capital (such as human capital) will invest much more in the other source (such as social capital).

Ours is therefore among the first attempts to address complementarity or substitutability of human and social capital in developing countries. Human capital is generally categorized into three components: education (referred to as prior knowledge), experience and learning. Here we will concentrate particularly on the indirect impact of network participation contingent on professional education and industry experience achieved. The following two hypotheses are adopted:

Hypothesis 3.1: Entrepreneurs who participate in formal business networks will be more successful, if they have high level of professional education.

Hypothesis 3.2: Entrepreneurs who participate in formal business networks will be more successful, if they have more industry experience.

\section{Overview of Data}

The 2005-survey and 2007-survey are a follow-up on the three surveys carried out in collaboration between the Institute of Labour Studies and Social Affairs (ILSSA) in the Ministry of Labour, Invalids and Social Affairs (MOLISA) and Department of Economics, University of Copenhagen with funding from DANIDA. The previous surveys included a comprehensive survey from 1991 of some 1,000 enterprises in the three major cities and five provinces, a repeat survey in 1997 of some 400 of the same enterprises, and a parallel survey in the same year of a further 500 enterprises not previously studied, a repeat survey in 2002 of approximately 1,600 enterprises of which 750 firm were repeat enterprises, and a repeat survey in 2005 of approximately 2,800 enterprises in 10 provinces (with around 1,400 repeat firms). The final survey in 2007 covers 2,635 firms in the same 10 provinces (three urban cities Hanoi and HCMC and seven rural provinces Hai Phong, Ha Tay, Phu Tho, Nghe An, Quang Nam, Khanh Hoa, Lam Dong and Long An), in which up to 2,298 firms are repeat ones from 2005. Since the paper just aims to study start-up firms, these 2,298 repeat firms will be filtered to 
produce the final sample for analysis consisting of 1,398 firms aged from 1 to 9 years. ${ }^{1}$ It is supposed that their performance truly reflects entrepreneurial performance.

For reasons of implementation, the survey was confined to specific areas in 10 provinces. The sample was drawn randomly from a complete list of enterprises, where the stratified sampling procedure was used to ensure the inclusion of an adequate number of enterprises in each province with different ownership types, including household, private, partnership/collective, limited liability companies and joint stock companies. It can be said that the DANIDA dataset covering five points in time is the most successful and useful input for research purposes and policy making due to two reasons: (i) the surveys use the questionnaire sharing many of the same features (although additional modules have been added) to ascertain that the way they are implemented is as similar as possible; (ii) this kind of survey makes it especially important that the quality of the survey data is very good. Analysis of the development of enterprises over time will only be possible if the quality of the data collected for individual enterprises are of very high quality in all surveys. ${ }^{2}$

Table 1 documents the percentage of each category of firm-level control variables in order to judge the relative representativeness of our selected sample for the whole sample of 2005 and 2007. Regarding legal ownership types, it is noteworthy that household ownership is the most common ownership form before the launch of Company Law and Law on Private Enterprise in 1991 and Enterprise Law in 2000. The promulgation of these Laws has created a legal playing ground for the emergence of private firms, limited liabilities and joint stocks. Since the selected sample consists of only start-up firms (establishing from 1995 till 2004), and thus, compared to the corresponding percentage of each ownership form in the two original samples, households are slightly under-represented whereas private firms, limited liability, and joint stocks are over-represented. Together with the increasing popularity of private firms, limited liability and joint stocks, strong entrepreneurial spirit has also been pushed into urban business environments since most of these firms under small and medium size concentrate in big cities as Hanoi and Hochiminh city. Therefore, the final selected sample incurs a slight over-representation of urban-located firms and small and

\footnotetext{
${ }^{1}$ Prior studies on "start-up" firms generally use size and age thresholds to construct an appropriate sample, with maximum ages set from 10 to 12 years since founding. Empirical research using this upper bound of firm age to delineate start-up firms includes Ostgaard and Birley (1996); Stuart et al. (1999). Another reason for focusing on firms established from 1995 is that this allows to investigate the whole development process of the private sector since the introduction of Company Law and Law on Private Enterprise in 1990 - which created the landmark for the emergence and development of private firms in Vietnam - until the promulgation of Enterprise Law in 2000, which infused a strong entrepreneurial spirit into the local business environment. Actually, up to $70 \%$ of firms in the sample were established after 2000. The other $30 \%$ were mostly established in the late 1990 s, with only $0.03 \%$ set up in 1995 .

${ }^{2}$ For a detailed description of sampling methodology for the DANIDA surveys, see Rand and Tarp (2007 and 2009).
} 
medium-sized ones compared to the original two samples. In summary, we could feel secure about the general representativeness of our sample in reflecting the characteristics of start-up entrepreneurs in Vietnam.

Table 1 - Representativeness of the selected sample relative to the original surveys

\begin{tabular}{|c|c|c|c|c|c|}
\hline \multicolumn{2}{|c|}{ Categories } & $\begin{array}{c}2005 \text { sample } \\
(\%)\end{array}$ & $\begin{array}{c}2007 \text { sample } \\
(\%)\end{array}$ & $\begin{array}{l}\text { Repeat firms } \\
\text { sample (\%) }\end{array}$ & $\begin{array}{c}\text { Selected } \\
\text { sample (\%) }\end{array}$ \\
\hline \multirow{5}{*}{$\begin{array}{c}\text { Ownership } \\
\text { types }\end{array}$} & Households & 68.27 & 67.97 & 67.73 & 61.09 \\
\hline & Private & 10.10 & 7.93 & 10.15 & 11.23 \\
\hline & Partnership & 3.73 & 4.14 & 3.62 & 3.72 \\
\hline & Ltd liability & 15.74 & 17.42 & 16.33 & 21.03 \\
\hline & Joint stock & 2.16 & 2.47 & 2.18 & 2.94 \\
\hline \multirow{2}{*}{$\begin{array}{c}\text { Firm } \\
\text { location }\end{array}$} & Urban & 35.77 & 35.25 & 36.19 & 40.41 \\
\hline & Rural & 64.23 & 64.75 & 63.81 & 59.59 \\
\hline \multirow{3}{*}{ Firm size } & Micro-size & 63.84 & 65.9 & 63.37 & 58.02 \\
\hline & Small-size & 28.31 & 27.13 & 28.79 & 32.90 \\
\hline & Medium-size & 7.85 & 6.97 & 7.84 & 9.08 \\
\hline
\end{tabular}

Subjects answering the questionnaire are owners or managers of firms, who are called "entrepreneurs". The dataset contains a wide range of variables on demographic, innovation-related and economic factors including those relating to entrepreneurial characteristics, innovative features and business performance. The survey adopts a definition of small and medium sized enterprises (SMEs) consistent with the current World Bank and Vietnamese Government definition: Micro enterprises have up to 10 employees, small-scale enterprises up to 50 employees, and medium-sized enterprises up to 300 employees.

\section{Empirical Methodology and Results}

We follow Timmons (1994) to use profit to measure the accounting performance. ${ }^{3}$ To isolate the effects of different financial structures among firms and business cycle which creates interest fluctuation, the success measure 'profit' is equated to operating profit, i.e. profit after interests and tax. We use the log of operating profit to obtain the elasticity between firm performance and independent variables.

\footnotetext{
${ }^{3}$ For a review of the measures of the performance of entrepreneurial ventures, see Deeds et al. (1998).
} 
For logging to be possible we need to remove firms with negative profit from the selected sample. Of 1,398 firms, only six have negative profit. This is not surprising since year 2007 has been considered to be the most successful year for the Vietnamese economy in the recent period, with the highest GDP in the 2000s. Further, these six firms are located in four provinces and under three ownership forms, of which two are small and four are micro-sized. Thus, the exclusion of these six negative profit firms is assumed not to alter the representativeness of the selected sample.

To capture the causal effect of human capital and social capital variables overtime on the subsequent entrepreneurial performance, operating profit of 2007-survey will be used as the dependent variable; whereas depending on the fluctuating nature of independent variables, they will be selected either from the 2005-dataset or the 2007dataset. This is to impede the endogeneity bias that may be caused if cross-sectional data is used. Since most independent variables are dummies which remain quite stable overtime, the usual dynamic panel-data estimation (fixed-effects or random-effects regression) may not work properly. Ordinary least squares (OLS) with robust standard errors are used to estimate this relationship.

\subsection{Human Capital}

Human capital determinants include education, experience and learning. Education is often used as a proxy for prior knowledge, i. e. the knowledge attained before firm start-up which may have a partial effect on subsequent firm performance. Researchers claim that bias is likely to occur if OLS is adopted. This is because there may be unobserved individual characteristics, such as ability and motivation, that affect the schooling level attained and subsequent performance. However, most empirical research studies the effect of endogenous education in wage/income equations, in which different educational level or number of school years is taken as the main input to explain individual return in terms of wages and incomes. In such cases, important unobservable factors such as ability, motivation will bias the estimation and give misleading results. In our study, the effects of knowledge from individual learning and experience achieved during firm operations which we expect to exert a stronger impact on entrepreneurial performance are focused, under the assumption that other control variables to account for different individual and firm characteristics may offset the endogenous educational bias. 


\subsubsection{Human Capital Determinants of Entrepreneurial Performance}

Eight human capital variables are included (see Table 2). Education enters the analyses as a dummy variable, differentiating the high-educated business founders (university/college and technical high school) from the less educated ones (vocational training or no education). The experience of the business founder is measured in different dimensions: experience in business ownership itself (self-employment experience), experience in the industry in which the founder's business is active, and experience from working as employees. The general effect of experience will be the sum value of all these dimensions (each achieved experience dimension adds one point to the total general experience of entrepreneurs). Finally, the effect of knowledge from learning will be considered as the ability to accumulate knowledge to conduct innovation activities of three types: new product introduction, product innovation and process/technological innovation ${ }^{4}$. The variable ranges from 0 to 3 with each point standing for a specific type of innovation activities conducted. Since respondents of the two surveys could be different due to the change of ownership or inheritance, variables of education and experience will be extracted from the 2007-survey to directly attach to the respective respondents; whereas variables of knowledge from learning will be selected from the 2005-survey to capture the causal effect of innovation activities on the subsequent firm performance overtime.

\section{Table 2 Summary statistics of Human Capital independent variables}

\begin{tabular}{lccccc}
\hline \hline \multicolumn{1}{c}{ Variable } & Obs & Mean & Std. Dev. & Min & Max \\
\hline Age & 1392 & 45.43 & 10.48 & 21 & 89 \\
Professional education & 1392 & 0.33 & 0.47 & 0 & 1 \\
Experience & 1392 & 1.002 & 0.502 & 0 & 2 \\
Self-employment exp & 1392 & 0.356 & 0.479 & 0 & 1 \\
Industry experience & 1392 & 0.156 & 0.363 & 0 & 1 \\
Employee experience & 1392 & 0.489 & 0.5 & 0 & 1 \\
Learning & 1392 & 0.622 & 0.764 & 0 & 3 \\
New product introduction & 1392 & 0.051 & 0.219 & 0 & 1 \\
Product innovations & 1392 & 0.423 & 0.494 & 0 & 1 \\
Process innovations & 1392 & 0.147 & 0.354 & 0 & 1 \\
\hline \hline
\end{tabular}

\footnotetext{
4 "New product introduction" refers to the ability to bring / launch out a new product or service to market. The variable is operationalized by the answer of the question "Has the firm introduced new products since 2002?" By "product innovation", we mean the introduction of any improvements to the firm's existing goods or services. This includes, but is not limited to, improvements in functional characteristics, technical abilities, or ease of use. It is the answer of the question "Has the enterprise made any major improvements of existing products or changed specification since 2002?" Finally, "process/technological innovation" indicates the implementation of a new or significantly improved production or delivery method by developing or bringing new technology into widespread use. The variable is constructed by the answer of the question "Has the enterprise introduced new production processes/new technology since 2002?"
} 
The correlation matrix of independent variables is presented in Appendix A. A review of the correlations shows that of the 36 inter-correlations, 20 were significant at the .01 level. Thus, 55\% of the correlations are statistically significant. It should be noted, however, that the correlation analysis possessed sufficient power to detect statistically significant relationships with coefficients as small as 0.06 . As a result, many of the correlations are not substantive, even though they are statistically significant. It is also noteworthy that some variables by nature are inherently correlated, for instance between education and sub-components of experience, among sub-components of experience, and among sub-components of learning (product experience and industry experience; self-employment experience and employee experience; product innovation and new product introduction). 5 of the significant inter-correlations are negative due to (i) the negative impact of age; (ii) self-employment experience has negative correlation with employee experience.

We use three groups of controlling factors. First, with respect to individual characteristics of business owners, we will include age and gender of business owners (extracted from the 2007-survey). Second, regarding to characteristics of new firm itself, we include the age, size (in terms of employees), and ownership type of firms (from the 2005-survey).

\subsubsection{Estimation Results}

Table 3 shows results from the OLS estimation with robust standard errors of human capital equation ${ }^{5}$. The entrepreneur's human capital is seen to influence the entire set of performance measures. From regression (1), parameters on the main human capital inputs (education, experience, learning) are positive and significantly different from zero, which enables us to conclude that hypothesis 1 - human capital positively influences the performance of start-up firms - is confirmed. To be more specific, we will look at each main independent variable in details:

Professional education is significantly greater than zero, which plays an essential role in differentiating the performance of entrepreneurs. Although the decreasing magnitude of the 'education' coefficient diminishes the economic importance of educational level when ownership types are controlled, highly educated entrepreneurs

\footnotetext{
${ }^{5}$ The White $(\mathrm{chi} 2=133.82$, $\mathrm{p}$-value $=0.002)$ and Breusch Pagan $(\mathrm{chi} 2=26.8$, $\mathrm{p}$-value $=0.000)$ test indicates the presence of heteroskedasticiy, robust OLS estimation is adopted for the human capital equation.
} 
are able to make approximately $34 \%$ more profits than low educated ones do. Significant ownership type variables reveal that earned profits are divergent partly due to specific features of the firm's ownership type, which reduces quickly the numerical significance of education. As the based group is micro-sized household enterprises, it is plausible that education is less important to determine the entrepreneurial success. Overall, hypothesis 1.1 - positive relation between education and entrepreneurial performance - is strongly supported.

The former experience of the business founder appears to improve operating profit. When considering the specific dimension of experience, self-employment experience and industry experience are significant at $1 \%$ level. However, surprisingly, selfemployment experience, i.e. experience in activities related to business ownership, has negative relationship with generated profit, approximately $27 \%$ lower. Hypothesis 1.3 is rejected. A review of the literature (MacCrimmon and Wehrung, 1990; Norton and Moore, 2006), indeed, indicates a paradox of experience issues. On one hand, experience facilitates entrepreneurs' alertness to recognizing and exploiting entrepreneurial opportunities. On the other hand, experienced entrepreneurs may be less willing to take risks than nascent entrepreneurs with limited business experience. With informatics priors that permit more precise estimates, they are more risk-averse and more cautious to time compression, opportunity costs, and uncertainty. Business environment in an emerging market as Vietnam's keeps changing so rapidly that venture launch and exploitation growth opportunities really requires a risk neutral or risk loving mindset.

Ceteris paribus, entrepreneurs who used to do business in the same business line (industry experience) are likely to generate approximately $100 \%$ profits higher than industry new entrants. The effect is both numerically and statistically significant. Thus, hypothesis 1.2 (industry experience positively influence firm performance) are supported. While previous experience in setting up a business could make entrepreneurs more cautious to the riskiness of any entrepreneurial opportunities, industry experience brings them confidence and specialized knowledge of managing risks in a specific business line and hence more likely to capitalize recognized opportunities.

Knowledge from learning is seen to be very important in enhancing entrepreneurial performance. Statistically significant results strongly support hypothesis 1.4 (positive relation between learning and performance). Of those components of learning, knowledge from process innovation appears to have the strongest power both 
numerically and statistically. Everything else equal, those entrepreneurs having conducted process innovations are estimated to attain approximately $38 \%$ more profit than those having no process innovation.

Table 3 Estimation results: Impact of Human Capital on Entrepreneurial Performance

\begin{tabular}{|c|c|c|c|c|c|}
\hline \multirow{2}{*}{ Variables } & \multicolumn{5}{|c|}{ Operating Profit } \\
\hline & (1) & (2) & (3) & (4) & (5) \\
\hline Age & $\begin{array}{l}-0.008^{*} \\
(0.003)\end{array}$ & $\begin{array}{l}-0.008 \\
(0.003)\end{array}$ & $\begin{array}{l}-0.004 \\
(0.003)\end{array}$ & $\begin{array}{l}-0.004 \\
(0.003)\end{array}$ & $\begin{array}{l}0.0002 \\
(0.0027)\end{array}$ \\
\hline Professional education & $\begin{array}{l}1.104 * * \\
(0.082)\end{array}$ & $\begin{array}{l}1.102 * * \\
(0.082)\end{array}$ & $\begin{array}{l}0.934 * * \\
(0.081)\end{array}$ & $\begin{array}{l}0.928 * * \\
(0.082)\end{array}$ & $\begin{array}{l}0.344 * * \\
(0.075)\end{array}$ \\
\hline Experience & $\begin{array}{l}0.627 * * \\
(0.075)\end{array}$ & $\begin{array}{l}0.624 * * \\
(0.075)\end{array}$ & & & \\
\hline Self-employment experience & & & $\begin{array}{l}-0.292 * * \\
(0.092)\end{array}$ & $\begin{array}{l}-0.294 * * \\
(0.092)\end{array}$ & $\begin{array}{l}-0.271 * * \\
(0.085)\end{array}$ \\
\hline Industry exp & & & $\begin{array}{l}1.511 * * \\
(0.092)\end{array}$ & $\begin{array}{l}1.501 * * \\
(0.092)\end{array}$ & $\begin{array}{l}1.097 * * \\
(0.087)\end{array}$ \\
\hline Employee exp & & & $\begin{array}{l}-0.176 \\
(0.093)\end{array}$ & $\begin{array}{l}-0.175 \\
(0.093)\end{array}$ & $\begin{array}{l}-0.141 \\
(0.085)\end{array}$ \\
\hline Learning & $\begin{array}{l}0.52 * * \\
(0.049)\end{array}$ & $\begin{array}{l}0.52 * * \\
(0.049)\end{array}$ & & & \\
\hline New product & & & $\begin{array}{l}0.175 \\
(0.168)\end{array}$ & $\begin{array}{l}0.171 \\
(0.168)\end{array}$ & $\begin{array}{l}0.069 \\
(0.146)\end{array}$ \\
\hline Product innovation & & & $\begin{array}{l}0.449 * * \\
(0.07)\end{array}$ & $\begin{array}{l}0.452 * * \\
(0.069)\end{array}$ & $\begin{array}{l}0.324 * * \\
(0.061)\end{array}$ \\
\hline Process innovation & & & $\begin{array}{l}0.647 * * \\
(0.108)\end{array}$ & $\begin{array}{l}0.643 * * \\
(0.108)\end{array}$ & $\begin{array}{l}0.385^{* *} \\
(0.099)\end{array}$ \\
\hline Female & & $\begin{array}{l}0.007 \\
(0.075)\end{array}$ & $\begin{array}{l}0.003 \\
(0.07)\end{array}$ & $\begin{array}{l}0.01 \\
(0.07)\end{array}$ & $\begin{array}{l}-0.033 \\
(0.063)\end{array}$ \\
\hline Urban & & $\begin{array}{l}-0.029 \\
(0.07)\end{array}$ & $\begin{array}{l}0.003 \\
(0.066)\end{array}$ & $\begin{array}{l}0.014 \\
(0.067)\end{array}$ & $\begin{array}{l}0.0003 \\
(0.06)\end{array}$ \\
\hline Firm size - small & & & & $\begin{array}{l}-0.123 \\
(0.07)\end{array}$ & $\begin{array}{l}-0.156^{*} \\
(0.063)\end{array}$ \\
\hline - medium & & & & $\begin{array}{l}-0.055 \\
(0.12)\end{array}$ & $\begin{array}{l}0.087 \\
(0.105)\end{array}$ \\
\hline Firm age & & & & $\begin{array}{l}-0.0003 \\
(0.0002)\end{array}$ & $\begin{array}{l}-0.0002 \\
(0.0002)\end{array}$ \\
\hline $\begin{array}{l}\text { The type of ownership } \\
\text { Private }\end{array}$ & & & & & $\begin{array}{l}0.83 * * \\
(0.121)\end{array}$ \\
\hline Partnership & & & & & $\begin{array}{l}0.846^{* *} \\
(0.231)\end{array}$ \\
\hline Limited liability co. & & & & & $\begin{array}{l}1.612 * * \\
(0.098)\end{array}$ \\
\hline Joint stock co. & & & & & $\begin{array}{l}1.637 * * \\
(0.252) \\
\end{array}$ \\
\hline R-squared & 0.2994 & 0.2995 & 0.3902 & 0.3928 & 0.5088 \\
\hline Observations & 1392 & 1392 & 1392 & 1392 & 1392 \\
\hline
\end{tabular}

Note: $\quad$ - Standard errors are in parentheses

- ** Significant at $1 \%$ level, * Significant at $5 \%$ level

- Based group: Low-educated male entrepreneurs owning micro-sized, household enterprises.

With respect to the control variables, the following results are worth mentioning:

(i) Statistically, the significant negative sign of 'age' parameter shows the negative relationship between entrepreneurs' age and their entrepreneurial profit gained. 
A ten-year older entrepreneur is estimated to earn approximately $8 \%$ profit less. This result confirms previous findings by Holmes and Schmitz (1996), Reynolds and White (1997), and Van Praag (2003) that show a negative relationship between the two variables: aging makes the contribution of the founder progressively less valuable for company performance. However, the effect of age on entrepreneurial performance is not significant statistically and numerically when control variables are added in.

(ii) there is no significant divergence in entrepreneurial performance between males and females; urban-located firms (in big cities including Hanoi and Hochiminh) and rural-located ones.

(iii) bigger firms tend to earn lower profits, but the divergence is only significant when comparing the performance of micro-sized firms and the one of smallsized firms. Age of the firm does not have any impact, which is reasonable to the extent that all sampled firms are characterized as newly start-up firms.

\subsection{Social Capital}

This section aims at exploring (i) the effect of strong-tie and weak-tie individual network on entrepreneurial performance of firms, and (ii) the importance of strong-tie and weak-tie interaction to entrepreneurs' business performance. It is necessary to capture the effects of strong-tie informal networks, i.e. relations with family, relatives, and friends, on entrepreneurship in Vietnam where the community culture favoring mutual trust and reciprocity is appreciated. With respect to the effects of weak-tie formal networks, there is not yet any academic research on formal network participation as an important source of firms' social capital. This is because networks remain a relatively new concept that has just gained attention recently from Vietnamese policymakers as a beneficial recipe for the enhancement of entrepreneurial performance. Only with the launch of the Enterprise Law in 2000 did the Vietnamese government begin to develop networks in different industries in order to support non-state firms operating in these industries (cf. Tran-Nam and Pham, 2003). Robust OLS estimation is used again with operating profit of 2007 adopted as the performance measure and different social capital variables extracted from the 2005 survey. 


\subsubsection{Social Capital Determinants of Entrepreneurial Performance}

There is no doubt that the success of new businesses depends on a broad range of factors and that network support is only one part of the picture. For a more convincing and robust test of the network success hypothesis, it is necessary to have a model that controls for relevant influences on success of new businesses. Four groups of variables are included as follows:

Group 1 - Human capital: significant human capital variables from the above regression are included in 3 sub-components: professional education, experience, and learning to prevent omitted variable bias.

Group 2 - Social capital from weak-tie networks: the effect of formal business networks (partners, bank officials, authority, mass organizations, etc) will be captured: (i) formal business network participation, which is a dummy attaining value one if the entrepreneur joins one or more than one network, ${ }^{6}$ and zero otherwise; (ii) network usefulness, which is included as an interaction term with network participation. The aim is to explore whether those firms who already participate in networks and find them useful and beneficial for their operation are actually better performers; (iii) network intensity, i.e. frequency of network assistance, which is operationalized by the answer of the question "how many times a year the entrepreneur receives the assistance in issues directly related to the operation of his firm?"; (iv) network size, which is the sum of regular contacts (at least once every 3 months) that entrepreneurs find useful for their business operations in 4 categories (business people in the same line of business and in different lines of business, bank officials, and mass organizations); (v) network support in terms of finance that verifies whether business partners are the main creditor of firms' obtained loans; and (vi) network support in terms of production activities that verifies whether a firm subcontracts (or outsourcing) parts of its production to others.

Group 3 - Social capital from strong-tie networks: to get an impression about the role of family members, relatives and friends in both the start-up and growth period of new businesses, three variables are constructed: (i) financial support, captured by the percentage of initial investment capital as loans from family/friends; (ii) emotional support, explained by two variables: number of family members working as selfemployer and family/friends as the guarantor of obtained loans.

\footnotetext{
${ }^{6}$ The dummy combines the answers to two questions: "Do you participate in one business network?" and "Do you participate in more than one network?"
} 
Group 4 - Interaction between social capital and human capital: two interaction variables will be included to verify the indirect effect of network participation on subsequent entrepreneurial performance depending on the type of human capital obtained, e.g., professional education and industry experience.

In terms of control variables, beside age and gender of entrepreneurs, location and ownership types of their firms, we include a dummy to distinguish performance of Communist party members from that of non-members. In a one-party political system like Vietnam's, holding membership of the Party could be considered as the social advantage that facilitates business operations. He/she may get more access to governmental assistance due to the inherently close relation between Party members and the government. Table 4 presents summary statistics of proposed independent variables. Their correlation matrix is placed in Appendix B.

A review of the correlations shows that of the 65 inter-correlations, 16 are significant at the .01 level. Thus, $23 \%$ of the correlations are statistically significant. However, the majority of correlation coefficients are not numerically significant, even though they are statistically significant. Several strong pair-wise correlations among independent variables include age / experience; network size/ network participation; and education / network participation, which are intuitively and inherently interrelated.

Table 4 Summary statistics of Social Capital independent variables

\begin{tabular}{|c|c|c|c|c|c|}
\hline Variable & Obs & Mean & Std. Dev. & Min & Max \\
\hline Network participation & 1392 & 0.114 & 0.318 & 0 & 1 \\
\hline Network usefulness & 1392 & 0.092 & 0.288 & 0 & 1 \\
\hline Network size & 1392 & 32.79 & 52.79 & 1 & 175 \\
\hline Network intensity & 1392 & 22.07 & 103.92 & 0 & 241 \\
\hline Business partners as the main creditor & 1392 & 0.385 & 0.486 & 0 & 1 \\
\hline Subcontract parts of production & 1392 & 0.068 & 0.252 & 0 & 1 \\
\hline $\begin{array}{l}\text { Percentage of internal capital as loans from } \\
\text { relatives/friends }\end{array}$ & 1392 & 10.20 & 19.89 & 0 & 100 \\
\hline Number of entrepreneurs in the family & 1392 & 0.247 & 0.64 & 0 & 5 \\
\hline Family/friends as the guarantor of loans & 1392 & 0.044 & 0.205 & 0 & 1 \\
\hline Communist party membership & 1392 & 0.0872 & 0.282 & 0 & 1 \\
\hline
\end{tabular}

\subsubsection{Estimation Results}

Table 5 shows estimated effects of human and social capital determinants as well as their interaction on subsequent entrepreneurial performance measured by operating profit. 
Consistent with the findings from the human capital equation above, all human capital determinants have significant and positive relations with entrepreneurial performance. Among them, professional education shows a larger numerical effect in all regression specifications: other things equal, entrepreneurs who have higher professional education are estimated to generate approximately $30 \%$ profit higher. Startup experience and accumulated knowledge from innovation activities (learning) are also important human capital determinants for entrepreneurs to enhance their profits.

For the effect of weak-tie networks, network participation has a significant positive effect on entrepreneurial performance. Ceteris paribus, network members are likely to outperform non-members by $50 \%$. However, network participation loses its statistical and economic significance once legal ownership types are controlled. Thus, hypothesis 2.2 on the existence of a positive relationship between weak-tie support and firm success is somewhat supported, but not strongly. Since most of formal business networks in Vietnam have been established by the government for political reasons, for instance, explaining newly-promulgated laws and regulations, network membership normally just brings participating entrepreneurs political advantages rather than business support.

The significant positive effect of network participation is mainly reflected through network size, rather than network intensity. In other words, the quality of network assistance, i.e. number of useful and regular contacts directly associated with daily operations of firms, is essentially more important than the quantity, or frequency, of network assistance. However, the economic positive effect of network size is somewhat trivial: about $0.2 \%$ profit higher, which is the reward for those having more useful and regular network contacts.

The effects of strong-tie networks, in general, are insignificant, even negatively related to entrepreneurial success. Unlike other empirical studies (e.g., Bruderl and Preisendorfer, 1998) financial support from strong ties, operationalized as percentage of loans from family, relatives or friends in the total initial investment capital, does not play a role in determining successful entrepreneurship. Loans obtained from friends or relatives are normally trust-based, i.e. without monthly interest pressure and specific due dates, and thus, do not stimulate entrepreneurs' commitment to their firm success. On overall, hypothesis 2.1 on the existence of a positive relationship between strong-tie support and firm success is not supported. 
Table 7 Estimates of the Entrepreneurial Performance equation

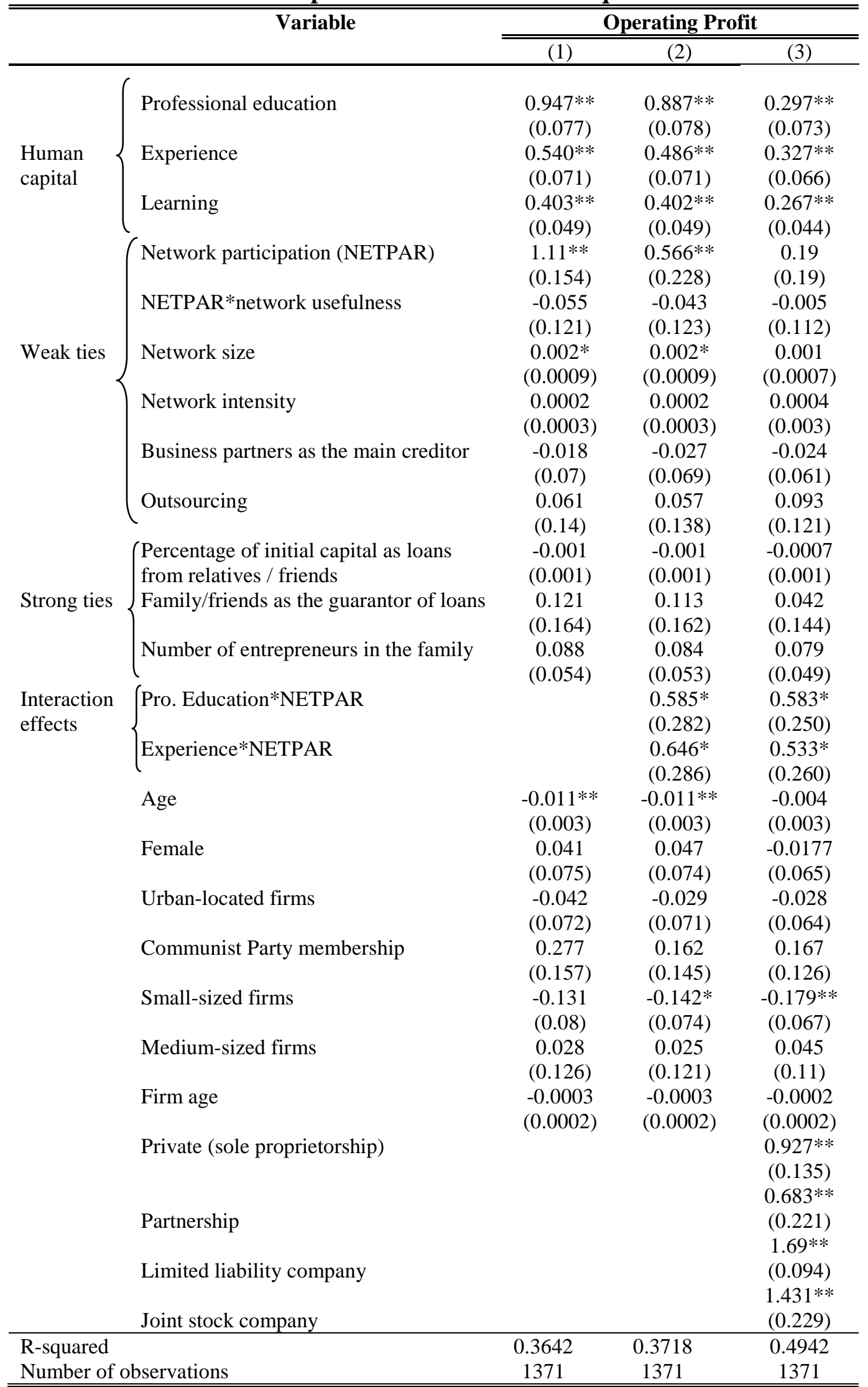

Note: OLS regression is reported with robust standard errors in parentheses. The based group is microsized enterprises, rural-located with male owners;

* significant at $5 \%$ level; ** significant at $1 \%$ level 
The interaction terms between professional education and experience with network participation have quite significant positive effect on firm-level operating profit. The economic effects are large: other things held constant, entrepreneurs who participate in formal networks are estimated to boost up approximately 58\% profit higher if they attained high level of professional education; as well increase approximately 53\% profit higher if they have industry experience. Both hypothesis 2.3 and 2.4 are supported.

Empirically, positive and significant coefficients of the human capital variable and the social capital variable in the same equation mean that they are substitutable. And a positive and significant coefficient for the interaction term between human and social capital implies complementarity. But a positive and significant interaction coefficient together with positive (significant) coefficients for human and social capital imply complementarity, but with some substitutability at the margin (Rooks et al., 2009). With this reasoning, the interaction terms between network participation and education / industry experience are positive and significant, indicating complementarity of human and social capital in the profit equation. Furthermore, the positive coefficients of both network participation and human capital variables (education or experience) indicate that there is substitutability at the margin.

Figure 1(a) constructs conditional-effects plots to indicate the correlation between network participation and $\min / \max$ value of professional education. In other words, two regression lines are computed to represent the effect of network participation on the high educational group (top line) and the low educational group (bottom line). It is clear from the graph that network membership has a different effect for each group: the higher the educational level, the greater is the increase of profit with increasing likelihood of network participation. The divergence is much larger when we consider the correlation between network participation and the lowest as well as highest level of start-up experience achieved (Figure 1b). In models without interaction terms, the lines in a conditional-effects plot would always be parallel.

Communist party membership is not significant. It merely ensures that the entrepreneur may be a member of a particular formal network, but does not guarantee that he has a successful performance. In terms of control variables, consistent with above findings, age of the entrepreneur has a negative relationship with his firm performance; no significant divergence regarding entrepreneurial performance of female entrepreneurs and male ones, urban-located firms and non-urban ones. Small-sized firms are estimated to underperform significantly relatively to micro-sized counterparts. 
And finally, private firms, partnership, limited liability, and joint stock firms are all more successful than household firms that are mainly micro-sized and rural-located (based group).

Figure 1 Conditional-effects plot

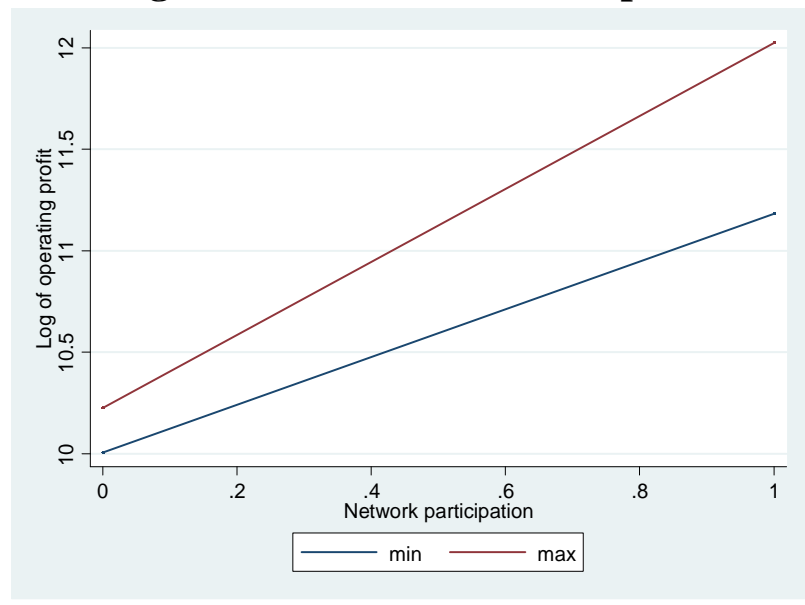

(a) Interaction between

network participation and professional education

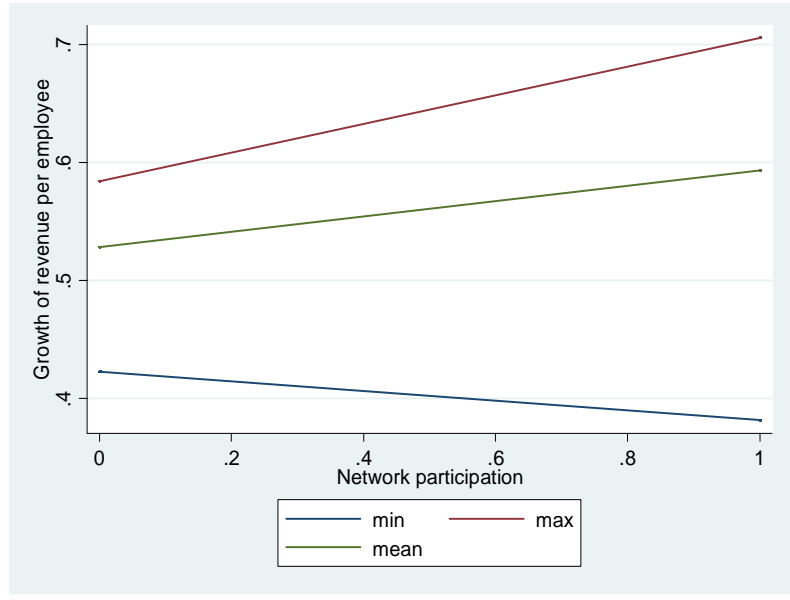

(b) Interaction between network participation and start-up experience

\section{Final Discussions}

\subsection{Human Capital}

Generally, we found a positive relationship between human capital and the success of start-up firms (Hypothesis 1 is supported). Specifically, education, industry experience, and learning all positively and significantly influence entrepreneurial performance (Hypothesis 1.1, 1.2, and 1.4 are supported). Entrepreneurial experience, on the other hand, has negative impact on firm profitability, which does not support hypothesis 1.3. This could be due to the fact that experienced entrepreneurs from their cautious screening process are more risk-averse and less willing to capitalize recognized profitable opportunities. Among these factors, education and learning have strongly significant economic effects on firm success; conversely, experience gradually loses its significance when more control variables are added (ownership types). Nevertheless, the high numerical magnitude of industry experience demonstrates its importance in contributing entrepreneurial knowledge to Vietnamese business founders. They operate in a transitional business environment with weak legal systems, complex administrative burdens, and little support from business development services that prior knowledge from education at school does not prepare them adequately for start-up activities. 
With respect to learning effects, product innovations and process innovations show a strong positive relation with the overall performance. On the contrary, the introduction of new products is insignificantly correlated with entrepreneurial profits. This is actually not surprising since developing a new product requires a lot of effort, time and capital, while the likelihood of profitability cannot be assured. In fact, previous empirical research supports this finding, showing that a number of new products disappeared shortly after becoming available in the market (Cooper, 1984; Hultink and Robben, 1995. According to Hultink and Robben (1995), that a new product can be considered as a success or a failure depends on the relationship between a company's time perspective and its choice of criteria for measuring new product success. These authors submit that in the short term profitability cannot serve as an appropriate indicator of success due to high sunk costs of developing new products; accordingly, criteria such as development cost and speed-to-market are more important.

In terms of policy implications, our study confirms that specific investments of business founders in professional education, experience, and learning will significantly enhance their performance. However, these investments do not always bring comparatively similar benefits at any moment in life. As aging makes the contribution of the founder progressively less valuable for the company performance, entrepreneurs should take into account their age when they decide to make a human capital investment.

\subsection{Social Capital}

Our analysis supports intuitions and findings of previous authors (Granovetter, 1973; Fukuyama, 1995; Davidsson and Honig, 2003) that entrepreneurs could gain more benefits from weak-tie business networks than from strong-tie emotional interactions. Tangible benefits such as subcontracting parts of production show significant magnitude. Hypotheses 2.1 is not supported, whereas hypothesis 2.2 is supported. This looks surprising since the evidence works against popular opinions that the informality of business environment in Vietnam highlights the role of close interactions with family, relatives, and friends in stimulating entrepreneurial activities.

A possible explanation is that network is such a new concept that people in Vietnam hardly refer to it when they attempt to explain successful entrepreneurship. Although support from strong ties is always available to help business founders to overcome startup difficulties, the real tangible benefits are unexpectedly vague. Loans from relatives 
and friends without monthly interest pressure may limit the entrepreneur's motivation and commitment to his/her venture success. On the other hand, Support from weak ties has quite strong effect on firm performance, but loses its statistical significance when ownership types are taken into account. This comes from the reality that entrepreneurs are involved in formal network activities for political advantages, rather than businessrelated supports.

Although network members are more likely to do business with each other and assist each other in difficult times, this benefit is not numerically strong. Business associations in Vietnam still restricts their performance in supporting merely legal and political issues, such as updated information on newly-launched business-related regulations or punishing any member or non-member not obeying industry rules. On the other hand, there is no statistical evidence that the frequency of assistance received from networks (network intensity) is related to benefits gained.

Thus, social capital brought by formal network participation is still very limited in Vietnam. Conversely, the evidences of social capital benefits from business network participation are widely observed in many transitional economies: in Russia (Batjargal, 2000), in Eastern Europe (Paldam and Svendsen, 2000) and in China (Koch, 2005). Therefore, policies from the Vietnamese government should encourage the establishment and development of business-oriented networks (rather than politicsbased ones) to support directly entrepreneurs, especially those of small-sized firms, in both their daily operations and long-term strategic management.

\subsection{Interaction of Human and Social Capital}

The most suggestive finding in our study is that entrepreneurs $d o$ create values by combining their social and human capital. Both hypothesis 2.3, i.e. positive relation between interaction of network participation and high educational level and hypothesis 2.4, i.e. positive relation between interaction of network participation and start-up experience are supported. This reflects the positive indirect effects of network participation on firm performance, depending on the type of human capital that entrepreneurs possess, e.g., professional education or start-up experience.

We find both complementarity and substitutability between network participation and professional education, but complementarity vanishes when experience is taken into account. Experience loses its significance when the interaction terms are controlled. 
Also, the first-order coefficients of experience and network participation are positive, resulting in substitutability at the margin.

\subsection{Main limitations and directions for future research}

A weakness of our study is that tests of social capital effects are limited to the extent that we have not been allowed by the available data to isolate various characteristics of networks: functions, strength of ties, density, degree of centrality, etc. The limitations of available data may exclude some dimensions of social capital and of human capital which may be substitutable one to another. Our findings on the interaction between human capital and social capital are therefore only suggestive rather than conclusive. Further research need to capture unique network characteristics for the Vietnamese case in order to "capitalize social capital" (Ellerman, 1996: 14) in a way that fully exploits the inherent benefits of social capital.

In this connection, the paper by Banerjee and Munshi (2004) on the misallocation of capital in the garment sector in the town of Tirupur (India) provides some useful insights. In Tirupur there are two types of entrepreneurs: locals, which belong to the Gounders - a network of wealthy landowners - and outsiders that joined the town to set up factories. Banerjee and Munshi (2004) document that the Gounders run significantly larger and more vertically integrated firms, most likely because of a much superior access to capital. Overtime, however, the outsiders catch up. The main driver of this catching up process has been shown by Banerjee and Munshi (2004) being the fact that, since the Gounders have access to capital because of their networks they do not need to be as good or productive as the outsiders to survive in the industry. So, it is those firms that are larger and more capitalized that grow slower and are less productive. This would be fully justifiable in economic terms if capital and "talent" were substitutes, but within-network evidence suggests they are not. Hence the evidence points at a significant misallocation of resources, with profits and revenues growth per employee driven by higher access to capital, with little or no relationship to efficiency/productivity.

The Banerjee and Munshi (2004) insights allow us to acknowledge some possible shortcomings of our analysis. First, there is the issue of how success is measured: Operating profit could be driven by higher access to capital, with little or no relationship to efficiency/productivity. Second, we are unable to tell whether the entrepreneurs that "need" to rely upon strong ties, e.g. family, to survive are the good ones or the bad ones. 
Without further research allowing dynamics of cohort and age effects to be controlled, we cannot be sure whether the reported effect would be upwardly biased. 


\section{Appendix A. Correlation Matrices}

\section{A.1. Correlation Matrix of Variables in Human Capital Equation}

\begin{tabular}{|c|c|c|c|c|c|c|c|c|}
\hline & Age & $\begin{array}{l}\text { Professional } \\
\text { Education }\end{array}$ & $\begin{array}{c}\text { Industry } \\
\text { Experience }\end{array}$ & $\begin{array}{l}\text { Employee } \\
\text { Experience }\end{array}$ & $\begin{array}{c}\text { Self- } \\
\text { employment } \\
\text { Experience }\end{array}$ & $\begin{array}{l}\text { New Product } \\
\text { Introduction }\end{array}$ & $\begin{array}{c}\text { Product } \\
\text { Innovation }\end{array}$ & $\begin{array}{c}\text { Process } \\
\text { Innovation }\end{array}$ \\
\hline Age & 1.0000 & & & & & & & \\
\hline $\begin{array}{l}\text { Professional } \\
\text { Education }\end{array}$ & -0.0158 & 1.0000 & & & & & & \\
\hline $\begin{array}{l}\text { Industry } \\
\text { Experience }\end{array}$ & -0.0406 & $0.2084 *$ & 1.0000 & & & & & \\
\hline $\begin{array}{l}\text { Employee } \\
\text { Experience }\end{array}$ & $0.1363 *$ & $0.3423 *$ & $0.0978^{*}$ & 1.0000 & & & & \\
\hline $\begin{array}{c}\text { Self- } \\
\text { employment } \\
\text { Experience }\end{array}$ & $-0.0704 *$ & $-0.347 *$ & $-0.1316^{*}$ & $-0.7281 *$ & 1.0000 & & & \\
\hline $\begin{array}{l}\text { New Product } \\
\text { Introduction }\end{array}$ & 0.0210 & 0.0664 & $0.00885^{*}$ & 0.00604 & -0.036 & 1.0000 & & \\
\hline $\begin{array}{l}\text { Product } \\
\text { Innovation }\end{array}$ & $-0.0894 *$ & $0.1348^{*}$ & $0.0807 *$ & $0.0763^{*}$ & $-0.0813 *$ & $0.1314^{*}$ & 1.0000 & \\
\hline $\begin{array}{l}\text { Process } \\
\text { Innovation }\end{array}$ & -0.013 & $0.1677 *$ & $0.1595^{*}$ & $0.122 *$ & $-0.0985^{*}$ & 0.152 & $0.3258^{*}$ & 1.0000 \\
\hline
\end{tabular}




\section{Appendix B. Correlation Matrix of Variables in Social Capital Equation}

\begin{tabular}{|c|c|c|c|c|c|c|c|c|c|c|c|c|}
\hline & Age & Education & Experience & Learning & $\begin{array}{l}\text { Strong- } \\
\text { tie } \\
\text { Capital }\end{array}$ & $\begin{array}{c}\text { Strong- } \\
\text { tie. } \\
\text { Guarantor }\end{array}$ & $\begin{array}{c}\text { Family } \\
\text { Entrepreneur }\end{array}$ & $\begin{array}{c}\text { Network } \\
\text { Participation }\end{array}$ & $\begin{array}{l}\text { Network } \\
\text { Size }\end{array}$ & $\begin{array}{l}\text { Network } \\
\text { Intensity }\end{array}$ & $\begin{array}{c}\text { Weak- } \\
\text { tie } \\
\text { Creditor }\end{array}$ & Outsourcing \\
\hline Age & 1.0000 & & & & & & & & & & & \\
\hline Education & -0.0158 & 1.0000 & & & & & & & & & & \\
\hline Experience & 0.0392 & $0.1605 *$ & 1.0000 & & & & & & & & & \\
\hline Learning & -0.0578 & $0.1840 *$ & $0.1288^{*}$ & 1.0000 & & & & & & & & \\
\hline $\begin{array}{l}\text { Strong } \\
\text { Capital }\end{array}$ & 0.0299 & 0.0068 & 0.0469 & -0.0323 & 1.0000 & & & & & & & \\
\hline $\begin{array}{c}\text { Strong } \\
\text { Guarantor }\end{array}$ & 0.0356 & $-0.055^{*}$ & -0.0009 & -0.0343 & 0.0469 & 1.0000 & & & & & & \\
\hline $\begin{array}{c}\text { Family } \\
\text { Entrepreneurs }\end{array}$ & 0.0156 & -0.0046 & 0.0303 & -0.0383 & 0.0376 & 0.0363 & 1.0000 & & & & & \\
\hline $\begin{array}{c}\text { Network } \\
\text { Participation }\end{array}$ & $0.0838 *$ & $0.2088 *$ & $0.1599^{*}$ & $0.2628 *$ & 0.0032 & -0.0006 & 0.0031 & 1.0000 & & & & \\
\hline Network Size & -0.0289 & $0.1095 *$ & $0.0818 *$ & $0.1009 *$ & 0.0141 & -0.0146 & 0.0075 & $0.1566^{*}$ & 1.0000 & & & \\
\hline $\begin{array}{l}\text { Network } \\
\text { Intensity }\end{array}$ & -0.0365 & 0.0083 & -0.0244 & -0.0190 & -0.012 & 0.0677 & -0.0243 & 0.0358 & $0.1399 *$ & 1.0000 & & \\
\hline $\begin{array}{c}\text { Weak } \\
\text { Creditor }\end{array}$ & -0.0173 & 0.0196 & -0.0122 & 0.0115 & 0.0409 & $0.1435^{*}$ & 0.0023 & -0.0292 & 0.0033 & 0.031 & 1.0000 & \\
\hline Outsourcing & 0.0087 & -0.008 & -0.0012 & -0.0002 & -0.009 & $0.0799 *$ & -0.0202 & -0.0072 & 0.0304 & -0.0031 & $0.0723^{*}$ & 1.0000 \\
\hline
\end{tabular}

Note: *: significant at $1 \%$ level 


\section{References}

Abramovitz, M. (1989). Thinking about growth. Cambridge: Cambridge University Press.

Aldrich, H., \& Reese, P.R. (1993). Does networking pay off? A panel study of entrepreneurs in the research triangle. In: N.S. Churchill et al. (Eds.), Frontiers of entrepreneurship research 1993. Boston: Babson College.

Aldrich, H., \& Zimmer, C. (1986). Entrepreneurship through social networks. In D. Sexton \& R.Smilor (Eds.), The art and science of entrepreneurship. New York: Ballinger.

Banerjee, A., \& Munshi, K. (2004). How efficiently is capital allocated? Evidence from the knitted garment industry in Tirupur. Review of Economic Studies, 71:19-42.

Barney, J.B. (1995). Advanced strategic management. Reading (MA): Addison-Wesley.

Barney, J.B., Wright, M., \& Ketchen Jr., D.J. (2001). The resource-based view of the firm: Ten years after 1991. Journal of Management, 27: 625-641.

Bates, T. (1997). Race, Self-Employment, and Upward Mobility: An Illusive American dream. Washington (DC): Woodrow Wilson Center Press.

Bates, T.M. (1994). Social resources generated by group support networks may not be beneficial to asian immigrant-owned small businesses. Social Forces, 72: 671-89.

Bates, T., \& Servon L. (2000), Viewing self-employment as a response to lack of suitable opportunities for wage work. National Journal of Sociology, 12: 23-55.

Baum, J.A.C., \& Silverman, B.S (2004). Picking winners or building them? Alliance, intellectual, and human capital as selection criteria in venture financing and performance of biotechnology startups. Journal of Business Venturing, 19: 411-436.

Birley, S. (1985). The role of networks in the entrepreneurial process. Journal of Business Venturing, 1: 107-117.

Bosma N.S., Van Praag, C.M., Thurik A.R., \& De Wit. G. (2004). The value of human and social capital investments for the business performance of startups. Small Business Economics, 23: 227-236.

Brown, B., \& Butler, J.E. (1995). Competitors as allies: a study of entrepreneurial networks in the U.S. wine industry. Journal of Small Business Management, 3: 57-66.

Bruderl, J., \& Preisendorfer, P. (1998). Network support and the success of newly founded businesses. Small Business Economics, 10: 213-225.

Brush, C.G., Greene P.G., \& Hart ,M.M. (2001). From initial idea to unique advantage: the entrepreneurial challenge of constructing a resource base. Academy of Management Executive, 15: 64-78.

Burt, R. S. (2001) .Structural holes versus network closure as social capital. In N. Lin, K. Cook \& R. S. Burt (Eds.), Networks and organizations. (pp. 31-56). New York: Walter de Gruyter.

Calabrese, T., Baum, J.A.C., \& Silverman, B. (2000). Canadian biotechnology start ups, 1991-1997: the role of incumbents' patents and strategic alliances in controlling competition. Social Science Research, 29: 503534.

Cohen, W., \& Levinthal, D. (1990). Absorptive capacity: A new perspective on learning and innovation, Administrative Science Quarterly. 35: 128-153.

Coleman, J. (1988). Social capital in the creation of human capital. American Journal of Sociology, 94: 95-120.

Cooper, A. C., Gimeno-Gascon, F.J., \& Woo, C.Y. (1994). Initial human and financial capital as predictors of new venture performance. Journal of Business Venturing, 9: 371-395.

Davidsson, P., \& Honig, B. (2003). The role of social and human capital among nascent entrepreneurs. Journal of Business Venturing, 18: 301-331.

Dencker, J.C., Gruber, M., \& Shah, S.K. (2009). Individual and opportunity factors influencing job creation in new firms. Academy of Management Journal, 52: 1125-1147.

Deeds, D., DeCarolis, D., \& Coombs, J.E. (1998). Firm-specific resources and wealth creation in high technology ventures: Evidence from newly public biotechnology firms. Journal of Business Venturing, 12: 31-46.

Ellerman, D. (1996). Entrepreneurship development in transitional economies. Washington (DC): World Bank.

Florin, J., Lubatkin, M., \& Schulze, W. (2003), A social capital model of high growth ventures. Academy of Management Journal, 46: 374-384.

Fukuyama, F. (1995). Trust: The social virtues and the creation of prosperity. New York: Free Press.

Gimeno, J., Folta, T. B., Cooper, A. C., \& Woo, C. Y. (1997). Survival of the fittest? Entrepreneurial human capital and the persistence of underperforming firms. Administrative Science Quarterly, 42: 750-783.

Granovetter, M. (1973). The strength of weak ties. American Journal of Sociology, 78: 1360-1380.

Greve, A., \& Salaff, J.W. (2003). Social networks and entrepreneurship. Entrepreneurship: Theory and Practice, 28: $1-22$.

Gustafsson, R., \& Autio, E. (2011). A failure trichotomy in knowledge exploration and exploitation. Research 
Policy, 40: 819-831.

Hamilton, B. (2000). Does entrepreneurship pay? An empirical analysis of the returns to self-employment. Journal of Political Economy, 108: 604-31.

Hebert, R., \& Link, A. (1988). The Entrepreneur: Mainstream views and radical critiques. 2nd ed. Westport (Conn.): Greenwood Publishing Group.

Hoang, H., \& Antoncic, B. (2003). Network-based research in entrepreneurship: A critical review. Journal of Business Venturing, 18: 165-187.

Holmes, T. J., \& Schmitz, J.A. (1996). Managerial tenure, business age and small business turnover. Journal of Labor Economics, 14: 79-99.

Hultink, E.J., \& Robben, H.S.J. (1995). Measuring new product success: The difference that time perspective makes. Journal of Product Innovation Management, 12: 392-405.

Jarillo, J.C. (1989). Entrepreneurship and growth: The strategic use of external resources. Journal of Business Venturing, 4: 133-147.

Johannisson, B. (1988). Business formation - A network approach. Scandinavian Journal of Management, 4: 83-99.

Jovanovic, B. (1982). Selection and the evolution of industry. Econometrica, 50: 649-670.

Kirzner, I. (1997). Entrepreneurial discovery and the competitive market process: An Austrian approach. Journal of Economic Literature, 35: 60-85.

Koch, B. J. (2005). Social capital in China: An experimental approach. Paper presented at the $100^{\text {th }}$ Annual Meeting of the American Sociological Association (ASA), Retrieved 2008-08-21 from

http://www.allacademic.com/meta/p20678_index.html

Lerner, M., \& Almor, T. (2002). Relationships among strategic capabilities and the performance of women-owned small ventures. Journal of Small Business Management, 40: 109-125.

Lerner, M., Brush, C.G., \& Hisrich, R.D. (1995). Factors affecting performance of Israeli women entrepreneurs: An examination of alternative perspectives. In: W.B. Bygrave et al. (Eds.). Frontiers of Entrepreneurship Research 1995. Boston:Babson College.

Levinthal, D.A., \& March, J.G. (1993). The myopia of learning. Strategic Management Journal, 14 (Special Issue: Organizations, Decision Making, and Strategy): 95-112.

Light, I. (1984), Immigrant and ethnic enterprise in North America. Ethnic and Racial Studies, 7: $195-216$.

Littunen, H. (2000), Networks and local environmental characteristics in the survival of new firms. Small Business Economics, 15: 59-71.

Malerba, F. (2007). Innovation and the dynamics and evolution of industries: Progress and challenges. International Journal of Industrial Organization, 25: 675-699.

MacCrimmon, K.R., \& Wehrung, D.A. (1990). Characteristics of risk taking executives. Management Science, 36: 422-435.

Miguel, E., Gertler, P., \& Levine, D. I. (2005). Does social capital promote industrialization? Evidence from a rapid industrializer. The Review of Economics and Statistics, 87: 754-762.

Minniti, M. and Bygrave, W.B. (2001), A dynamic model of entrepreneurial learning. Entrepreneurship: Theory and Practice, 25: 5-16.

Norton, W.I., \& Moore, W.T. (2006). The influence of entrepreneurial risk assessment on venture launch or growth decisions. Small of Business Economics, 26: 215-226.

Ostgaard, T.A., \& Birley, S. (1996). New venture growth and personal networks. Journal of Business Research, 36: 37-50.

Paldam, M., \& Svendsen, G.T. (2000). Missing social capital and the transition in Eastern Europe. Aarhus School of Business, Departmnt of Economics, Working Paper \#00-5.

Parker, S.C., \& Van Praag, C.M. (2006). Schooling, capital constraints, and entrepreneurial performance: The endogenous triangle. Journal of Business and Economic Statistics, 24: 416-431.

Pennings, J.M., Lee, K., \& Van Witteloostuijin, A. (1998). Human capital, social capital, and firm dissolution. Academy of Management Journal, 41: 425-440.

Peters, M., \& Brush, C. (1996). Market information scanning activities and growth in new ventures: A comparison of service and manufacturing businesses. Journal of Business Research, 36: 81-89.

Pickles, A.R., \& O'Farrell, P.N. (1987). An analysis of entrepreneurial behaviour from male work histories. Regional Studies, 21: 425-444.

Piazza-Georgi, B. (2002) .The role of human and social capital in growth: Extending our understanding. Cambridge Journal of Economics, 26: 461-479.

Putnam, R. (1993). Making democracy work: Civic traditions in modern Italy. Princeton: Princeton University Press.

Rand, J., \& Tarp, F. (2007). Characteristics of the Vietnamese business environment: Evidence from a SME Survey in 2005. A Study Prepared under Component 5 - Business Sector Research of the Danida Funded Business 
Sector Program Support (BSPS).

Rand, J., \& Tarp, F. (2009). Credit constraints and determinants of the cost of capital in Vietnamese manufacturing. Small Business Economics, 29: 1-13.

Reuber, A.R., \& Fischer, E. (1994). Entrepreneur's experience, expertise, and the performance of technology based firms. IEEE Transactions on Engineering Management, 41: 365-374.

Reuber, A.R., \& Fisher, E. (1999). Understanding the consequences of founders' experience. Journal of Small Business Management, 37: 30-45.

Reynolds, P. D. (1993). High performance entrepreneurship: What makes it different?. In: N.C. Churchill et al. (Eds.) Frontiers in Entrepreneurship Research 1993. Boston: Babson College.

Sanders, J., \& Nee, V. (1996). Immigrant self-employment: The family as social capital and the value of human capital. American Sociological Review, 61: 231-249.

Santarelli, E., Carree, M., \& Verheul, I. (2009). Unemployment and firm entry and exit: An update on a controversial relationship. Regional Studie, 43: 1061-1073.

Santarelli, E., \& Tran, H. T. (2011). Growth of incumbent firms and entrepreneurship inVietnam. University of Bologna - Department of Economics Working Paper \# 785.

Say, J. B. [1803 (1971)] A treatise on political economy of the production, distribution and consumption of wealth. New York: A.M. Kelley.

Schiller, B.R., \& Crewson, P.E. (1997). Entrepreneurial origins: A longitudinal inquiry. Economic Inquiry, 35: 523531.

Schumpeter, J.A. (1934). The theory of economic development: An inquiry into profits, capital credit, interest and the business cycle. Cambridge (MA): Harvard University Press.

Shane, S. (2000). Prior knowledge and the discovery of entrepreneurial opportunities. Organization Scienc, 11: 448469.

Shane, S., \& Venkataraman, S. (2000). The promise of entrepreneurship as a field of research. Academy of Management Review, 25: 217-226.

Smeltzer, L.R., Van Hook, B.L., \& Hutt, R.W. (1991). Analysis and use of advisors as information sources in venture startups. Journal of Small Business Management, 29: 10-20.

Sonnentag, S., \& Frese, M. (2002). Performance concepts and performance theory. In: S. Sonnentag (Ed.), Psychological management of individual performance: A handbook in the psychology of management in organizations. (pp. 3-25). Chichester: Wiley.

Storey, D.J. (1994). Understanding the small business sector. London: International Thomson Business Press.

Stuart, T.E., Hoang, H., \& Hybels, R. (1999). Interorganizational endorsements and the performance of entrepreneurial ventures. Administrative Science Quarterly, 44: 315-349.

Szirmai, A. (2008). Explaining success and failure in development. UNU-MERIT Working Paper \#2008- 013. Maastricht: UNU-MERIT.

Taylor, M. (1999). Survival of the fittest? An analysis of self-employment duration in Britain. Economic Journal, 109: $140-155$.

Timmons, J.A. (1994), New venture creation, 4th Edition. Irwin (IL): Burr Ridge.

Tran-Nam, B., \& Pham, Ch. D. (Eds.) (2003). The Vietnamese Economy: Awakening the Dormant Dragon. London: RoutledgeCurzon.

Van der Sluis, J., Van Praag, C.M., \& Vijverberg, W. (2003). Entrepreneurship selection and performance: A metaanalysis of the impact of education in industrialized countries. The World Bank Economic Review, 19: 225261.

Van Praag, C. M., \& Cramer, J.S. (2001). The roots of entrepreneurship and labor demand: Individual ability and low risk aversion. Economica, 269: 45-62.

Van Praag, C.M. (2005). Successful entrepreneurship: Confronting economic theory with empirical evidence. Cheltenham: Edward Elgar.

Yoon, I. (1991). The changing significance of ethnic and class resources in immigrant business: The case of Korean immigrant businesses in Chicago. International Migration Review, 25: 303-331.

Zahra, S.A., \& George, G. (2002). International entrepreneurship: The current status of the field and future research agenda. In: M. Hitt, R. Ireland, M. Camp. D. Sexton (Eds.) Strategic leadership: creating a new mindset. (pp. 255-288). London: Basil Blackwell.

Zimmer, C., \& Aldrich, H. (1987). Resource mobilization through ethnic networks: kinship and friendship ties of shopkeepers in England. Sociological Perspectives, 30: 422-445. 


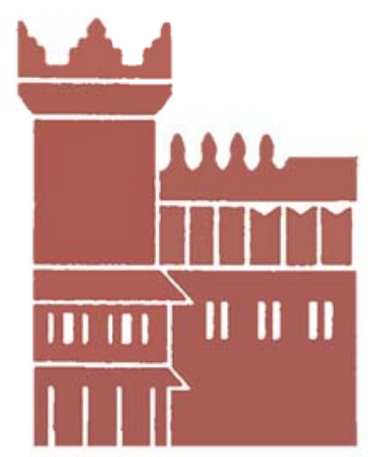

Alma Mater Studiorum - Università di Bologna DEPARTMENT OF ECONOMICS

Strada Maggiore 45

40125 Bologna - Italy

Tel. +39051 2092604

Fax +390512092664

http://www.dse.unibo.it 